\title{
A comparison of three xylanases on the nutritive value of two wheats for broiler chickens
}

\author{
M. Choct $^{1 *}$, A. Kocher ${ }^{1}$, D. L. E. Waters ${ }^{1,2}$, D. Pettersson ${ }^{3}$ and G. Ross ${ }^{4,5}$ \\ ${ }^{1}$ School of Rural Science and Agriculture, University of New England, Armidale, NSW 2351, Australia \\ ${ }^{2}$ Centre for Plant Conservation Genetics, Southern Cross University, Lismore, NSW 2480, Australia \\ ${ }^{3}$ Novozymes A/S, 2880 Bagsvaerd, Denmark \\ ${ }^{4}$ Novozymes Australia Pty Ltd, PO Box 4942, North Rocks, NSW 2151, Australia \\ ${ }^{5}$ DSM Nutritional Products, Frenchs Forest, NSW 2086, Australia
}

(Received 12 September 2003 - Revised 4 February 2004 - Accepted 9 March 2004)

\begin{abstract}
Three xylanase products, xylanase A derived from Thermomyces lanuginosus, xylanase B from Humicola insolens and xylanase C from Aspergillus aculeatus, were examined for their effects on the nutritive value of wheat. The study investigated the effects of enzyme addition to broiler diets based on a low-metabolisable-energy (ME) wheat and a normal-ME wheat, with the emphasis on changes in composition of the NSP along the digestive tract in broiler chickens. There were significant $(P<0 \cdot 01)$ enzyme and wheat effects on the apparent ME, but there was no wheat $\times$ enzyme interaction on apparent ME. Weight gain and feed conversion efficiency (except xylanase $C$ for normal wheat) were also significantly $(P<0 \cdot 01)$ increased by the xylanases. The enzymes differed in their effect on a number of important nutritional parameters. Xylanase A reduced $(P<0.05)$ the excreta moisture level from $77.1 \%$ in birds fed the normal-ME wheat control to $73.4 \%$ and from $77.4 \%$ in those fed the low-ME wheat to $73.0 \%$. The other two enzymes did not affect excreta moisture levels. The digesta viscosity in the duodenum, jejunum and ileum of birds fed both types of wheat was reduced $(P<0 \cdot 01)$ by xylanases $\mathrm{A}$ and $\mathrm{C}$, but was increased $(P<0.01)$ in the jejunum and ileum by xylanase B. The digestibility of the soluble NSP was mostly negative in the small intestine. The digestibility of the insoluble NSP differed $(P<0.01)$ between the two wheats, with those in the low-ME wheat being more digestible $(14$ v. $28 \%)$. When supplemented with xylanase A, the ileal digestibility of the insoluble NSP in the normaland low-ME wheats was increased by 28 and $42 \%$, respectively. Xylanases B and C did not affect the digestibility of the insoluble NSP regardless of wheat type. It may be concluded that wheats with low or normal ME values vary in their responses to xylanase supplementation. Apart from having an elevated level of soluble NSP, low-ME wheat may also contain insoluble NSP, which in the present study appeared to be more easily degradable in the gut of the chicken.
\end{abstract}

Poultry: Enzymes: Non-starch polysaccharides: Nutritive value of wheat

Nutritionists are often not able to test raw ingredients and establish a true feeding value in advance of use in commercial feed formulations. Variation in raw ingredients accounts for $30 \%$ of the variation in the finished product and creates multiplicative effects together with weighing errors (Fawcett \& Webster, 1996). Subsequently, the diet may not reach the required specifications, which can result in sub-optimal performance and economic loss.

The apparent metabolisable energy (AME) values of Australian wheat have been reported to range from 10.35 to $15.9 \mathrm{MJ} / \mathrm{kg}$ DM (Mollah et al. 1983; Rogel et al. 1987). The so-called 'low-metabolisable energy (ME) wheats' are defined as wheats having AME values under $13 \mathrm{MJ} / \mathrm{kg}$ DM for poultry (Mollah et al. 1983). Approximately $30 \%$ of Australian wheats fall into this category. When low-ME wheats are included as the main energy source in broiler diets, sticky and watery droppings will appear immediately, followed by growth depression and poor feed efficiency. Wheat contains $5-8 \%$ arabinoxylans (pentosans, consisting of the monosaccharides arabinose and xylose linked in $\beta$ 1-4 linkages with arabinose side chains through the $\mathrm{O} 2$ and/or $\mathrm{O} 3$ positions of the backbone), up to $1 \%$ of $\beta$-glucans and $2-3 \%$ of cellulose. These NSP are believed to be the major cause of the low-ME wheat phenomenon (Annison \& Choct, 1991). The viscous nature of these polysaccharides has a direct influence on nutrient absorption as well as interacting with the gut microflora and modifying the physiological function of the gut. High levels of soluble NSP raise digesta viscosity in the intestine of chickens leading to reduced starch, protein and lipid digestion (Choct \& Annison, 1990; Annison, 1991; Philip et al. 1995). It is well documented that the addition of commercial feed enzymes to wheat-based broiler diets generally results in 
a significant improvement in performance and a reduction in the occurrence of wet and sticky droppings (Annison, 1992; Choct et al. 1994). Xylanases reduce the intestinal viscosity of birds by degradation of soluble arabinoxylans. The degree of degradation of these polymers in the intestinal tract of broilers is unknown. When a depolymerised pentosan preparation was added to a broiler diet its antinutritive effect largely disappeared (Choct \& Annison, 1992a). But the digesta viscosity of birds fed this diet was significantly higher in comparison with birds fed a sorghum-based control diet. This finding suggests that a reduction in viscosity might not be the only parameter of importance influencing the AME value of wheat.

Detailed knowledge of the substrates and their breakdown pattern in the intestine of chickens is required in order to fully comprehend the effects of wheat NSP. The present study was carried out to test the hypothesis that the nutritive value of wheat for poultry is related to the viscous nature of the soluble NSP as well as the encapsulation of nutrients by cell-wall components of the grain, namely the insoluble arabinoxylans. Thus, enzymes that have affinity for both these fractions could be superior to one that reduces viscosity alone or that attacks mainly the cell walls.

\section{Materials and methods}

\section{Bird husbandry}

A total of 288 male broiler chicks (1-d-old; Cobb strain) were obtained from the Baiada Hatchery, Kotingal, New South Wales and were raised on a commercial broiler starter diet (crumbles, Ridley AgriProducts, Tamworth, NSW, Australia), containing $12.5 \mathrm{MJ} \mathrm{ME} / \mathrm{kg}$ and a minimum of $20 \%$ crude protein, in standard chick brooders for $24 \mathrm{~d}$. During experimentation, all birds were transferred to wiremesh metabolism cages situated in climate-controlled rooms. All experimental diets were cold-pelleted. The diets were then offered to the birds ad libitum and water was freely available. Birds were grown under continuous fluorescent lighting. The animal ethics committee of the University of New England approved the present study. Health and husbandry practices complied with the Code of Practice for the Care and Use of Animals for Scientific Purposes (National Health \& Medical Research Council, 1990) for the Commonwealth of Australia and the Australian Model Code of Practice for the Welfare of Animals (Standing Committee on Agriculture and Resource Management, 1995).

\section{Diet}

Two wheats with known low or normal ME values were chosen for the present study based on a preliminary study reported by Choct \& Kocher (2000). The low-ME wheat had a measured AME value of $12.5 \mathrm{MJ} / \mathrm{kg} \mathrm{DM}$ at the time of harvest, whereas the normal wheat had an AME value of $11.5 \mathrm{MJ} / \mathrm{kg} \mathrm{DM}$.

All diets were formulated using the ingredients and proportions shown in Table 1. First, the minor ingredients were mixed in a small rotary mixer and were then pooled with the major ingredients for thorough mixing. All experimental diets were identical in composition. Three xylanase products differing in their modes of action were selected for the present experiment. The enzymes were: xylanase A, which was purported to have affinity for both soluble and insoluble NSP; xylanase B, which was mainly known to solubilise insoluble NSP; xylanase C, which under laboratory conditions mainly reduced viscosity (Dr Dan Pettersson, Novozymes AS, Bagsvaerd, Denmark, personal communication.). Each tonne of feed contained $200 \mathrm{~g}$ xylanase A (activity, 1000 fungal xylanase unit/g; commercial name, Bio-Feed Wheat or Ronozyme WX; derived from Thermomyces lanuginosus), $250 \mathrm{~g}$ xylanase B (activity, 800 fungal xylanase unit/g; commercial name, Bio-Feed Plus or Ronozyme W; derived from Humicola insolens) or $426 \mathrm{~g}$ xylanase C (activity, 469 fungal xylanase unit/g; an

Table 1. Composition of the experimental diets $(\mathrm{g} / \mathrm{kg})$

\begin{tabular}{|c|c|c|c|c|c|c|c|c|}
\hline \multirow[b]{2}{*}{ Ingredients } & \multicolumn{8}{|c|}{ Diets } \\
\hline & 1 & 2 & 3 & 4 & 5 & 6 & 7 & 8 \\
\hline Normal-ME wheat (Currawong) & 784 & 784 & 784 & 784 & - & - & - & - \\
\hline Low-ME wheat (Harvey) & - & - & - & - & 784 & 784 & 784 & 784 \\
\hline Casein & 149 & 149 & 149 & 149 & 149 & 149 & 149 & 149 \\
\hline Dicalcium phosphate & $19 \cdot 6$ & 19.6 & $19 \cdot 6$ & $19 \cdot 6$ & $19 \cdot 6$ & $19 \cdot 6$ & $19 \cdot 6$ & $19 \cdot 6$ \\
\hline Limestone & $10 \cdot 8$ & $10 \cdot 8$ & $10 \cdot 8$ & $10 \cdot 8$ & $10 \cdot 8$ & $10 \cdot 8$ & $10 \cdot 8$ & $10 \cdot 8$ \\
\hline DL-Methionine & $6 \cdot 8$ & $6 \cdot 8$ & $6 \cdot 8$ & $6 \cdot 8$ & $6 \cdot 8$ & $6 \cdot 8$ & 6.8 & $6 \cdot 8$ \\
\hline Vitamin-mineral pre-mix ${ }^{*}$ & 4.9 & 4.9 & 4.9 & 4.9 & 4.9 & 4.9 & 4.9 & 4.9 \\
\hline Salt & 2.9 & $2 \cdot 9$ & $2 \cdot 9$ & $2 \cdot 9$ & $2 \cdot 9$ & $2 \cdot 9$ & $2 \cdot 9$ & $2 \cdot 9$ \\
\hline Choline chloride & $2 \cdot 0$ & $2 \cdot 0$ & $2 \cdot 0$ & $2 \cdot 0$ & $2 \cdot 0$ & $2 \cdot 0$ & $2 \cdot 0$ & $2 \cdot 0$ \\
\hline Marker† & $20 \cdot 0$ & $20 \cdot 0$ & $20 \cdot 0$ & $20 \cdot 0$ & $20 \cdot 0$ & $20 \cdot 0$ & $20 \cdot 0$ & $20 \cdot 0$ \\
\hline Xylanase Ał & - & 0.2 & - & - & - & 0.2 & - & - \\
\hline Xylanase B & - & - & 0.25 & - & - & - & 0.25 & - \\
\hline Xylanase C‡ & - & - & - & 0.426 & - & - & - & 0.426 \\
\hline
\end{tabular}

ME, metabolisable energy.

* The active ingredients contained in the vitamin-mineral premix were as follows (per $\mathrm{kg}$ ): retinol $3.03 \mathrm{mg}$, cholecalciferol $0.09 \mathrm{mg}$, all-rac- $\alpha$ tocopherol acetate $20 \mathrm{mg}$, menadione $6.3 \mathrm{mg}$, riboflavin $8 \mathrm{mg}$, pyridoxine hydrochloride $5 \mathrm{mg}$, biotin $0.01 \mathrm{mg}$, niacin $30 \mathrm{mg}$, thiamin $1.5 \mathrm{mg}$, D-calcium pantothenate $15 \mathrm{mg}$, folic acid $2 \mathrm{mg}$, ethoxyquin $125 \mathrm{mg}$, Mn $75 \mathrm{mg}, \mathrm{Fe} 20 \mathrm{mg}, \mathrm{Cu} 5 \mathrm{mg}, 11 \mathrm{mg}, \mathrm{Co} 0.3 \mathrm{mg}, \mathrm{Se} 0.5 \mathrm{mg}, \mathrm{Mo}$ $0.16 \mathrm{mg}$, cyanocobalamin $0.15 \mathrm{mg}$. 
experimental product derived from Aspergillus aculeatus). The activities were determined by Novozymes AS of Denmark. Celite was included to all diets at $20 \mathrm{~g} / \mathrm{kg}$ as a marker for the calculation of nutrient digestibility in the small intestine.

\section{Apparent metabolisable energy bioassay}

On day 24, chickens were weighed in groups of six and transferred to forty-eight metabolism cages. The first $3 \mathrm{~d}$ served as an adaptation period and for the last $4 \mathrm{~d}$ excreta were collected daily, dried overnight in a forced-air oven at $80^{\circ} \mathrm{C}$ and pooled for the determination of gross energy. The amount of feed consumed during the adaptation period and the excreta collection period was recorded. On completion of the $7 \mathrm{~d}$ AME bioassay period the birds were weighed in groups following their killing by cervical dislocation. The body cavity was opened and the contents of the duodenum, jejunum (from duodenum to the Meckel's diverticulum), ileum (from the Meckel's diverticulum to $40 \mathrm{~mm}$ above the ileo-caecal junction) and caecum were collected. Digesta of birds from each cage was pooled for the same gut section and fresh weights recorded. The supernatant fractions and the pellets were immediately separated by centrifugation $(12000 \mathrm{~g}, 15 \mathrm{~min})$ and frozen at $-21^{\circ} \mathrm{C}$ for future analyses.

The AME value of the major dietary ingredient (cereal) was obtained by using a pre-determined AME value (20.1 MJ/kg DM) for casein (Annison et al. 1994). The calculation of the AME of the grain was as follows:

$$
\begin{aligned}
\mathrm{AME}_{\text {grain }}= & \left(\mathrm{AME}_{\text {diet }}-\mathrm{AME}_{\text {casein }}\right. \\
& \times \text { dry casein level }) / \text { dry grain level. }
\end{aligned}
$$

\section{Laboratory analyses}

Digesta viscosity. Approximately $2 \mathrm{~g}$ fresh digesta were centrifuged $\left(12000 \mathrm{~g}, 10 \mathrm{~min}\right.$ at $\left.20^{\circ} \mathrm{C}\right)$ and the viscosity was determined on $0.5 \mathrm{ml}$ supernatant fraction using a Brookfield Model DV-III Rheometer (Brookfield Engineering Laboratories Corp., Stoughton, MA, USA) at $25^{\circ} \mathrm{C}$ with a CP40 cone and shear rate of 5-500/s. The samples did not exhibit shear thinning at these shear rates.

Volatile fatty acids. For caecal volatile fatty acid (VFA) determination, $3 \mathrm{~g}$ fresh sample were diluted with $0 \cdot 1 \mathrm{M}$-sulfuric acid $(3 \mathrm{ml})$ and thoroughly mixed. The sample was centrifuged $(12000 \mathrm{~g}, 15 \mathrm{~min})$. To a sample of $1 \mathrm{ml}$ supernatant fraction, $0.1 \mathrm{ml}$ of a reference VFA (caproic acid) were added. The VFA were distilled using Thundberg tubes. The concentration of VFA was quantified using a Hewlett Packard 427 gas-liquid chromatograph (Hewlett Packard, Palo Alto, CA, USA). For ileal VFA determination, the fresh sample was centrifuged $(12000 \mathrm{~g}, 15 \mathrm{~min})$. To a sample of $1.3 \mathrm{ml}$ supernatant fraction, $0.1 \mathrm{ml}$ of a reference VFA (caproic acid) and $0.5 \mathrm{M}-$ sulfuric acid $(0.1 \mathrm{ml})$ were added. The VFA were distilled using Thundberg tubes. The samples were treated with two drops of $10 \mathrm{M}$-sodium hydroxide and concentrated to dryness in a vacuum desiccator. The VFA salts were dissolved in $0.5 \mathrm{M}$-sulfuric acid $(0.1 \mathrm{ml})$ and were quantified using a Hewlett Packard 427 gas-liquid chromatograph. The gas chromatograph was fitted with a glass column packed with $o$-phosphoric acid $(1.5 \%, \mathrm{w} / \mathrm{w})$ and polypropylene glycol sebacate $(15.5 \%)$ on chromosorb 'W', acidwashed, 60-80 mesh. Operating conditions using a flame ionisation detector were: column temperature, $135^{\circ} \mathrm{C}$; detector temperature, $180^{\circ} \mathrm{C}$; carrier gas $\left(\mathrm{N}_{2}\right)$ flow, $25 \mathrm{~cm}^{3} / \mathrm{min} ; \mathrm{H}_{2}$ flow, $25 \mathrm{~cm}^{3} / \mathrm{min}$; air flow, $220 \mathrm{~cm}^{3} / \mathrm{min}$.

Proximate analyses. DM was determined using a drying oven at $105^{\circ} \mathrm{C}$ for $6 \mathrm{~h}$. Gross energy contents of diets and excreta were determined using a DDS 500 isoperibol calorimeter (Digital Data Systems, Johannesburg, South Africa). Acid-insoluble ash in the jejunal and ileal digesta was determined following the method described by Choct \& Annison (1992b). The $\mathrm{N}$ content of the diets and ileal digesta was determined using a LECO FP-2000 automatic analyser (LECO Corp., St Joseph, MI, USA). The protein contents were calculated using a multiplication factor of 5.7. Experimental diets and ileal digesta were analysed for soluble NSP, insoluble NSP and free sugars by the Uppsala method (Theander \& Westerlund, 1993).

\section{Statistical analysis}

All data were analysed using either Base SAS $®$ software (SAS Institute, Inc., 1988) or Statgraphics (Manugistics, Inc., 2000). ANOVA (by the general linear model procedure) was used to determine the significance of the main effects and any interactions, where appropriate. Duncan's multiple-range test was used to separate means when significant main effects $(P<0.05)$ were detected by ANOVA. When significant effects $(P<0.05)$ of interaction were evident from ANOVA, $t$ tests (by least-squares means procedure) were used to separate least-squares means.

\section{Results}

Bird performance, apparent metabolisable energy and excreta moisture

Xylanase supplementation increased $(P<0.001)$ the weight gain of birds compared with the unsupplemented controls regardless of wheat type. The feed conversion ratio followed a similar pattern, except for that in birds fed normal wheat with xylanase $\mathrm{C}$. The AME value of the unsupplemented wheat was higher in the present study compared with that reported in the preliminary study (Choct \& Kocher, 2000). However, there remained a difference of $1 \mathrm{MJ}$ between the two wheats, with the low$\mathrm{ME}$ wheat having an $\mathrm{AME}$ value lower than $13 \mathrm{MJ} / \mathrm{kg}$. The addition of enzymes to the normal-ME wheat had no effect on the AME values. In contrast, the addition of xylanases $\mathrm{A}$ and $\mathrm{C}$ to low-ME wheat significantly $(P<0.05)$ improved the AME value. Xylanase B had no effect on the AME value of the low-ME wheat. Xylanase A significantly $(P<0.05)$ reduced the moisture content of the excreta of birds fed both normal- and low-ME wheats, whereas the effect of xylanase B and xylanase $\mathrm{C}$ on excreta moisture was not significant. All the data are presented in Table 2 . 
Table 3. Amounts of free sugars, soluble and insoluble NSP (SNSP and iNSP), and total NSP in jejunal and ileal digesta of broiler chickens fed on diets containing normal-metabolisable energy (ME) wheat and low-ME wheat with and without enzyme supplementation (mg/g marker) $\dagger$ (Mean values)

\begin{tabular}{|c|c|c|c|c|c|c|c|c|c|}
\hline \multirow[b]{2}{*}{ Wheat } & \multirow[b]{2}{*}{ Enzyme } & \multicolumn{4}{|c|}{ Jejunum } & \multicolumn{4}{|c|}{ Ileum } \\
\hline & & Free sugars & sNSP & iNSP & Total NSP & Free sugars & sNSP & iNSP & Total NSP \\
\hline Normal-ME & Control & $2010 \cdot 2^{a b}$ & $487 \cdot 5^{\mathrm{c}}$ & $2527 \cdot 2^{a}$ & $5025 \cdot 0^{a}$ & $878 \cdot 9^{a b}$ & $509 \cdot 5^{\mathrm{cd}}$ & $2349 \cdot 5^{\mathrm{ab}}$ & $3737.9^{\mathrm{bcd}}$ \\
\hline Normal-ME & Xylanase A & $2039 \cdot 0^{a}$ & $640 \cdot 5^{\mathrm{ab}}$ & $2208 \cdot 5^{a b}$ & $4888 \cdot 0^{a}$ & $1019 \cdot 3^{a}$ & $547 \cdot 4^{c}$ & $1966 \cdot 5^{b}$ & $3533 \cdot 2^{\mathrm{cd}}$ \\
\hline Normal-ME & Xylanase B & $1971 \cdot 9^{a b}$ & $617 \cdot 4^{\mathrm{cb}}$ & $2001 \cdot 7^{b}$ & $4488 \cdot 2^{a}$ & $1010 \cdot 6^{a}$ & $807 \cdot 2^{\mathrm{a}}$ & $2500 \cdot 1^{a}$ & $4317 \cdot 8^{a}$ \\
\hline Normal-ME & Xylanase C & $1929 \cdot 8^{a b}$ & $513 \cdot 8^{b c}$ & $2548 \cdot 0^{a}$ & $4905 \cdot 9^{a}$ & $886 \cdot 6^{a b}$ & $539 \cdot 9^{c}$ & $2482 \cdot 5^{a}$ & $3909 \cdot 0^{\mathrm{abcd}}$ \\
\hline Low-ME & Control & $1579 \cdot 4^{\mathrm{b}}$ & $492 \cdot 1^{c}$ & $2637 \cdot 6^{a}$ & $4709 \cdot 1^{a}$ & $941 \cdot 2^{\mathrm{ab}}$ & $509 \cdot 2^{\mathrm{cd}}$ & $2609 \cdot 5^{\mathrm{a}}$ & $4060 \cdot 0^{\mathrm{ab}}$ \\
\hline Low-ME & Xylanase A & $1915 \cdot 1^{\mathrm{ab}}$ & $705 \cdot 3^{a}$ & $2416 \cdot 3^{a b}$ & $5036 \cdot 8^{a}$ & $1002 \cdot 3^{a}$ & $610 \cdot 0^{\mathrm{b}}$ & $1991 \cdot 2^{b}$ & $3603.5^{\mathrm{bcd}}$ \\
\hline Low-ME & Xylanase B & $2014 \cdot 4^{\mathrm{ab}}$ & $715 \cdot 5^{\mathrm{a}}$ & $2497 \cdot 6^{a}$ & $5227 \cdot 5^{\mathrm{a}}$ & $960 \cdot 9^{a}$ & $809 \cdot 0^{a}$ & $2235 \cdot 3^{a b}$ & $4005 \cdot 2^{\mathrm{bc}}$ \\
\hline Low-ME & Xylanase C & $1840 \cdot 7^{\mathrm{ab}}$ & $471.9^{c}$ & $2388 \cdot 4^{a b}$ & $4701 \cdot 0^{a}$ & $749 \cdot 3^{b}$ & $464 \cdot 6^{d}$ & $2221 \cdot 5^{\mathrm{ab}}$ & $3435 \cdot 4^{c}$ \\
\hline \multicolumn{10}{|c|}{ Probability of greater $F$ value in ANOVA } \\
\hline Wheat & & NS & NS & NS & NS & NS & NS & NS & NS \\
\hline Enzyme & & NS & $\star \star *$ & NS & NS & * & $* \star *$ & $\star \star$ & $\star \star$ \\
\hline Wheat $\times$ enzyme & & NS & NS & NS & NS & NS & * & NS & NS \\
\hline
\end{tabular}

a,b,c,d Values within a column with unlike superscript letters were significantly different $(P<0.05)$. ${ }^{\star} P<0.05,{ }^{* \star} P<0.01,{ }^{* \star *} P<0.001$.

†For details of diets and procedures, see Table 1 and p. 54.

only significant for diets containing the low-ME wheat. In contrast, the addition of xylanase B to the unsupplemented control diets increased intestinal viscosity throughout the intestine. In diets with low-ME wheat the increases were significant $(P<0.05)$ in all sections of the intestine.

\section{Digestibility of non-starch polysaccharide fractions}

The digestibility of soluble NSP was mostly negative, except in birds fed low-ME wheat supplemented with xylanase B. The negative effect of enzymes on the digestibility of soluble NSP both in the jejunum and ileum differed, with xylanase $B$ producing a highly negative $(P<0.05)$ ileal digestibility value compared with the other diets regardless of wheat type (Table 7). Both the jejunal and ileal digestibility values for the insoluble
NSP were significantly $(P<0 \cdot 01)$ higher for the low-ME wheat than the normal wheat. Xylanase A resulted in numerically higher digestibility values for the ileal insoluble NSP. There was a significant $(P<0.01)$ wheat $X$ enzyme interaction on the ileal digestibility of soluble NSP, with xylanase B giving a negative digestibility for the normal wheat and a positive digestibility value for the low-ME wheat.

\section{Volatile fatty acid production in the ileum and caecum}

The addition of enzymes to diets based on the normal-ME wheat had no effect on the production of VFA in the ileum or caecum (Table 8). In diets with low-ME wheat the addition of xylanases $\mathrm{A}$ and $\mathrm{C}$ reduced $(P<0.05)$ the VFA concentration in the ileum.

Table 4. Main neutral sugar composition in the jejunal and ileal digesta of broiler chickens fed diets containing normal-metabolisable energy (ME) wheat with and without enzyme supplementation $(\mathrm{g} / \mathrm{kg} \mathrm{marker})^{*}$

(Mean values)

\begin{tabular}{|c|c|c|c|c|c|c|c|}
\hline & \multirow[b]{2}{*}{ Enzyme } & \multicolumn{3}{|c|}{ Jejunum } & \multicolumn{3}{|c|}{ Ileum } \\
\hline & & Ara & Xyl & Glc & Ara & Xyl & Glc \\
\hline \multicolumn{8}{|l|}{ Free sugars } \\
\hline Normal-ME wheat & Control & $9 \cdot 2^{\mathrm{C}}$ & $5 \cdot 8^{c}$ & $1752 \cdot 8^{\mathrm{a}}$ & $6 \cdot 2^{\mathrm{c}}$ & $3.9^{c}$ & $695 \cdot 0^{\mathrm{a}}$ \\
\hline Normal-ME wheat & Xylanase A & $45 \cdot 1^{\mathrm{a}}$ & $115 \cdot 6^{\mathrm{a}}$ & $1635 \cdot 3^{\mathrm{a}}$ & $53 \cdot 9^{\mathrm{a}}$ & $138 \cdot 2^{\mathrm{a}}$ & $652 \cdot 5^{\mathrm{a}}$ \\
\hline Normal-ME wheat & Xylanase B & $10 \cdot 8^{\mathrm{C}}$ & $11 \cdot 8^{\mathrm{c}}$ & $1701 \cdot 5^{\mathrm{a}}$ & $10 \cdot 6^{\mathrm{bc}}$ & $11 \cdot 8^{\mathrm{bc}}$ & $788 \cdot 4^{\mathrm{a}}$ \\
\hline Normal-ME wheat & Xylanase C & $28 \cdot 6^{\mathrm{b}}$ & $67 \cdot 9^{\mathrm{b}}$ & $1611 \cdot 7^{\mathrm{a}}$ & $21 \cdot 9^{b}$ & $45 \cdot 0^{\mathrm{b}}$ & $632 \cdot 7^{\mathrm{a}}$ \\
\hline \multicolumn{8}{|l|}{ Soluble NSP } \\
\hline Normal-ME wheat & Control & $142 \cdot 3^{b}$ & $215 \cdot 0^{b}$ & $83 \cdot 2^{\mathrm{b}}$ & $141 \cdot 2^{c}$ & $224.4^{b}$ & $94 \cdot 6^{\mathrm{ab}}$ \\
\hline Normal-ME wheat & Xylanase $\mathrm{A}$ & $214 \cdot 8^{\mathrm{a}}$ & $289 \cdot 9^{a}$ & $105 \cdot 4^{\mathrm{a}}$ & $163 \cdot 3^{b}$ & $216 \cdot 1^{\mathrm{b}}$ & $122 \cdot 7^{\mathrm{ab}}$ \\
\hline Normal-ME wheat & Xylanase B & $198 \cdot 5^{\mathrm{a}}$ & $317 \cdot 7^{\mathrm{a}}$ & $77 \cdot 3^{\mathrm{b}}$ & $236 \cdot 6^{\mathrm{a}}$ & $413 \cdot 8^{\mathrm{a}}$ & $129 \cdot 2^{b}$ \\
\hline Normal-ME wheat & Xylanase C & $157 \cdot 0^{\mathrm{b}}$ & $219 \cdot 5^{b}$ & $89.0^{\mathrm{ab}}$ & $157 \cdot 5^{\mathrm{b}}$ & $229.0^{\mathrm{b}}$ & $101 \cdot 7^{\mathrm{ab}}$ \\
\hline \multicolumn{8}{|l|}{ Insoluble NSP } \\
\hline Normal-ME wheat & Control & $864.9^{a}$ & $1299 \cdot 0^{a}$ & $547 \cdot 1^{\mathrm{a}}$ & $764 \cdot 8^{\mathrm{a}}$ & $1233 \cdot 0^{a}$ & $532 \cdot 8^{\mathrm{a}}$ \\
\hline Normal-ME wheat & Xylanase A & $727 \cdot 7^{b}$ & $1007 \cdot 3^{b}$ & $601 \cdot 4^{\mathrm{a}}$ & $635 \cdot 9^{\mathrm{b}}$ & $939 \cdot 7^{b}$ & $519 \cdot 5^{\mathrm{a}}$ \\
\hline Normal-ME wheat & Xylanase B & $689 \cdot 9^{b}$ & $984 \cdot 0^{\mathrm{b}}$ & $449 \cdot 6^{\mathrm{a}}$ & $800 \cdot 4^{\mathrm{a}}$ & $1257 \cdot 2^{\mathrm{a}}$ & $617 \cdot 1^{\mathrm{a}}$ \\
\hline Normal-ME wheat & Xylanase $\mathrm{C}$ & $848 \cdot 4^{\mathrm{a}}$ & $1284.8^{\mathrm{a}}$ & $584 \cdot 2^{\mathrm{a}}$ & $806 \cdot 4^{\mathrm{a}}$ & $1315 \cdot 6^{\mathrm{a}}$ & $552 \cdot 8^{\mathrm{a}}$ \\
\hline
\end{tabular}

Ara, arabinose; Xyl, xylose; Glc, glucose.

a,b,c Values within a column with unlike superscript letters were significantly different $(P<0.05)$

${ }^{*}$ For details of diets and procedures, see Table 1 and p. 54. 
Table 5. Main neutral sugar composition in jejunal and ileal digesta of broiler chickens fed diets containing low-metabolisable energy (ME) wheat with and without enzyme supplementation ( $\mathrm{g} / \mathrm{kg} \mathrm{marker})^{\star}$

(Mean values)

\begin{tabular}{|c|c|c|c|c|c|c|c|}
\hline & \multirow[b]{2}{*}{ Enzyme } & \multicolumn{3}{|c|}{ Jejunum } & \multicolumn{3}{|c|}{ Ileum } \\
\hline & & Ara & Xyl & Glc & Ara & Xyl & Glc \\
\hline \multicolumn{8}{|l|}{ Free sugars } \\
\hline Low-ME wheat & Control & $7 \cdot 3^{\mathrm{c}}$ & $7 \cdot 6^{\mathrm{c}}$ & $1365 \cdot 6^{\mathrm{a}}$ & $5 \cdot 5^{\mathrm{c}}$ & $5 \cdot 2^{c}$ & $781 \cdot 2^{\mathrm{a}}$ \\
\hline Low-ME wheat & Xylanase $\mathrm{A}$ & $31.7^{\mathrm{a}}$ & $80 \cdot 5^{a}$ & $1587 \cdot 7^{\mathrm{a}}$ & $40 \cdot 2^{a}$ & $100 \cdot 7^{\mathrm{a}}$ & $707.9^{\mathrm{ab}}$ \\
\hline Low-ME wheat & Xylanase B & $9 \cdot 8^{\mathrm{C}}$ & $15 \cdot 0^{c}$ & $1756 \cdot 7^{\mathrm{a}}$ & $9 \cdot 1^{\mathrm{bc}}$ & $12 \cdot 9^{\mathrm{bc}}$ & $779 \cdot 8^{\mathrm{a}}$ \\
\hline Low-ME wheat & Xylanase C & $26 \cdot 7^{\mathrm{b}}$ & $60 \cdot 7^{b}$ & $1547 \cdot 4^{\mathrm{a}}$ & $18 \cdot 3^{\mathrm{b}}$ & $40 \cdot 0^{\mathrm{b}}$ & $562 \cdot 6^{\mathrm{b}}$ \\
\hline \multicolumn{8}{|l|}{ Soluble NSP } \\
\hline Low-ME wheat & Control & $158 \cdot 1^{b}$ & $221 \cdot 2^{b}$ & $65.9^{a}$ & $148 \cdot 4^{c}$ & $212 \cdot 1^{c}$ & $90 \cdot 2^{a}$ \\
\hline Low-ME wheat & Xylanase A & $254 \cdot 8^{\mathrm{a}}$ & $352 \cdot 1^{\mathrm{a}}$ & $81 \cdot 6^{\mathrm{a}}$ & $207 \cdot 4^{\mathrm{b}}$ & $278 \cdot 2^{b}$ & $88.6^{\mathrm{ab}}$ \\
\hline Low-ME wheat & Xylanase B & $247 \cdot 5^{a}$ & $372 \cdot 6^{\mathrm{a}}$ & $75 \cdot 8^{\mathrm{a}}$ & $262 \cdot 8^{\mathrm{a}}$ & $431.4^{\mathrm{a}}$ & $98 \cdot 9^{a}$ \\
\hline Low-ME wheat & Xylanase C & $160 \cdot 5^{b}$ & $199 \cdot 1^{\mathrm{b}}$ & $66 \cdot 5^{\mathrm{a}}$ & $150 \cdot 5^{c}$ & $199.4^{c}$ & $71 \cdot 3^{\mathrm{b}}$ \\
\hline \multicolumn{8}{|l|}{ Insoluble NSP } \\
\hline Low-ME wheat & Control & $903 \cdot 6^{\mathrm{a}}$ & $1368 \cdot 4^{\mathrm{a}}$ & $588 \cdot 1^{\mathrm{a}}$ & $857 \cdot 1^{\mathrm{a}}$ & $1405 \cdot 3^{\mathrm{a}}$ & $580 \cdot 2^{a}$ \\
\hline Low-ME wheat & Xylanase A & $790 \cdot 9^{\mathrm{a}}$ & $1162 \cdot 3^{\mathrm{a}}$ & $646 \cdot 3^{a}$ & $647 \cdot 8^{\mathrm{b}}$ & $986 \cdot 2^{\mathrm{C}}$ & $511.9^{a}$ \\
\hline Low-ME wheat & Xylanase B & $837.5^{\mathrm{a}}$ & $1255 \cdot 2^{\mathrm{a}}$ & $607 \cdot 3^{\mathrm{a}}$ & $729 \cdot 7^{\mathrm{b}}$ & $1149 \cdot 7^{\mathrm{bc}}$ & $539 \cdot 3^{\mathrm{a}}$ \\
\hline Low-ME wheat & Xylanase C & $815 \cdot 3^{\mathrm{a}}$ & $1201 \cdot 1^{a}$ & $556 \cdot 0^{\mathrm{a}}$ & $729 \cdot 2^{b}$ & $1186 \cdot 8^{\mathrm{a}}$ & $497 \cdot 2^{\mathrm{a}}$ \\
\hline
\end{tabular}

Ara, arabinose; Xyl, xylose; Glc, glucose.

a,b,c Values within a column with unlike superscript letters were significantly different $(P<0.05)$

${ }^{*}$ For details of diets and procedures, see Table 1 and p. 54.

\section{Discussion}

The use of enzymes to increase growth rate and feed conversion efficiency in poultry by removing the anti-nutritive effect of NSP is well established. In addition to enhancing nutrient utilisation, the enzymes also offer other benefits. These include an overall decrease in the output of organic matter in the excreta due to the better utilisation of nutrients, a reduction in the moisture content of the excreta due to decreased gut viscosity, and an improvement in animal health due to the prevention of diseases associated with the proliferation of gut microflora. There is also an increased precision and flexibility in least-cost feed formulation due to the reduced variability in the nutritive value of ingredients. However, these claims are not applicable to all xylanases as it is thought that xylanases differ in their efficacy in degrading arabinoxylans, perhaps due to their substrate affinity.
The present study demonstrated a number of clear differences in the modes of action of different xylanases in wheat-based poultry diets. First, the differences in their ability to reduce the moisture content of the excreta were large, although wheat type had no effect on excreta moisture in the present study. For example, xylanase A reduced the moisture level of the excreta from $77 \%$ in the control diet to $73 \%$. In the poultry industry, such a reduction means a change of the consistency of the excreta from a runny state to a dry, consistent form. Wet droppings are a big problem in the poultry industry, especially in laying hens where an increased percentage of dirty eggs is associated with wet and sticky excreta.

Second, to examine how xylanases with different modes of action exert their effect on the arabinoxylans in wheat, the present study measured the types and amounts of NSP present in various parts of the gut together with

Table 6. Duodenal, jejunal and ileal viscosity $(\mathrm{mPa} \times \mathrm{s})$ of broiler chickens fed diets containing normalmetabolisable energy (ME) wheat and low-ME wheat with and without enzyme supplementation $\dagger$ (Mean values and standard deviations)

\begin{tabular}{|c|c|c|c|c|c|c|c|}
\hline \multirow[b]{2}{*}{ Wheat } & \multirow[b]{2}{*}{ Enzyme } & \multicolumn{2}{|c|}{ Duodenum } & \multicolumn{2}{|c|}{ Jejunum } & \multicolumn{2}{|c|}{ lleum } \\
\hline & & Mean & SD & Mean & SD & Mean & SD \\
\hline Normal-ME & Control & $3 \cdot 3^{c}$ & 0.5 & $8 \cdot 0^{C}$ & $1 \cdot 2$ & $23 \cdot 3^{b c}$ & $4 \cdot C$ \\
\hline Normal-ME & Xylanase A & $2 \cdot 2^{d}$ & 0.3 & $4 \cdot 1^{d}$ & $0 . \overline{7}$ & $6 \cdot 8^{c}$ & $1 \cdot 1$ \\
\hline Normal-ME & Xylanase B & $3 \cdot 6^{b c}$ & 0.5 & $12 \cdot 3^{b}$ & $2 \cdot 4$ & $39 \cdot 7^{\mathrm{b}}$ & $6 \cdot 7$ \\
\hline Normal-ME & Xylanase C & $2 \cdot 3^{d}$ & 0.6 & $3 \cdot 3^{d}$ & 0.8 & $7 \cdot 7^{\mathrm{c}}$ & $4 \cdot 2$ \\
\hline Low-ME & Control & $4 \cdot 0^{\mathrm{b}}$ & 0.8 & $9 \cdot 4^{\mathrm{C}}$ & 0.8 & $28 \cdot 3^{b}$ & $5 \cdot 8$ \\
\hline Low-ME & Xylanase A & $2 \cdot 4^{\mathrm{d}}$ & 0.4 & $5 \cdot 2^{d}$ & $1 \cdot 8$ & $8 \cdot 3^{c}$ & $2 \cdot 7$ \\
\hline Low-ME & Xylanase B & $4 \cdot 7^{\mathrm{a}}$ & 0.6 & $18 \cdot 4^{a}$ & 4.5 & $84 \cdot 1^{a}$ & $42 \cdot 6$ \\
\hline Low-ME & Xylanase C & $2 \cdot 2^{d}$ & 0.6 & $3 \cdot 4^{\mathrm{d}}$ & 0.6 & $7 \cdot 2^{\mathrm{c}}$ & $2 \cdot C$ \\
\hline \multicolumn{8}{|c|}{ Probability of greater $F$ value in ANOVA } \\
\hline \multicolumn{2}{|c|}{ Wheat } & \multicolumn{2}{|c|}{ *** } & \multicolumn{2}{|c|}{$\star \star * *$} & \multicolumn{2}{|c|}{ ** } \\
\hline \multicolumn{2}{|l|}{ Enzyme } & \multicolumn{2}{|c|}{ 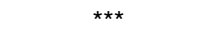 } & \multicolumn{2}{|c|}{ *** } & \multicolumn{2}{|c|}{ 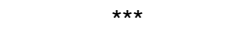 } \\
\hline \multicolumn{2}{|c|}{ Wheat $\times$ enzyme } & \multicolumn{2}{|c|}{ NS } & \multicolumn{2}{|c|}{$\star \star \star *$} & \multicolumn{2}{|c|}{ 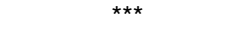 } \\
\hline
\end{tabular}

a,b,c Mean values within a column with unlike superscript letters were significantly different $(P<0.05)$.

${ }^{\star \star} P<0.01,{ }^{* \star \star} P<0.001$.

†For details of diets and procedures, see Table 1 and p. 54. 
Table 7. Digestibility of insoluble and soluble NSP (iNSP and SNSP) in jejunal and ileal digesta of broiler chickens fed diets containing normal-metabolisable energy (ME) wheat and low-ME wheat with or without enzyme supplementation $\dagger$

(Mean values)

\begin{tabular}{|c|c|c|c|c|c|}
\hline \multirow[b]{2}{*}{ Wheat } & \multirow[b]{2}{*}{ Enzyme } & \multicolumn{2}{|c|}{ Jejunum } & \multicolumn{2}{|c|}{ Ileum } \\
\hline & & iNSP & sNSP & iNSP & sNSP \\
\hline $\begin{array}{l}\text { Normal-ME } \\
\text { Normal-ME } \\
\text { Normal-ME } \\
\text { Normal-ME }\end{array}$ & $\begin{array}{l}\text { Control } \\
\text { Xylanase A } \\
\text { Xylanase B } \\
\text { Xylanase C }\end{array}$ & $\begin{array}{l}0.07^{\mathrm{b}} \\
0.19^{\mathrm{ab}} \\
0.26^{\mathrm{a}} \\
0.06^{\mathrm{b}}\end{array}$ & $\begin{array}{l}-0.11^{a b} \\
-0.13^{a b} \\
-0.21^{a b} \\
-0.38^{b}\end{array}$ & $\begin{array}{l}0.14^{\mathrm{cd}} \\
0.28^{\mathrm{abc}} \\
0.08^{\mathrm{b}} \\
0.09^{\mathrm{d}}\end{array}$ & $\begin{array}{l}-0.09^{a b} \\
-0.17^{b c} \\
-0.73^{d} \\
-0.15^{b c}\end{array}$ \\
\hline $\begin{array}{l}\text { Low-ME } \\
\text { Low-ME } \\
\text { Low-ME } \\
\text { Low-ME }\end{array}$ & $\begin{array}{l}\text { Control } \\
\text { Xylanase A } \\
\text { Xylanase B } \\
\text { Xylanase C }\end{array}$ & $\begin{array}{l}0.26^{a} \\
0.29^{a} \\
0.27^{a} \\
0.30^{a}\end{array}$ & $\begin{array}{l}-0.28^{a b} \\
-0.01^{a} \\
-0.24^{a b} \\
-0.41^{b}\end{array}$ & $\begin{array}{l}0.25^{\mathrm{bc}} \\
0.42^{\mathrm{b}} \\
0.35^{\mathrm{ab}} \\
0.35^{\mathrm{ab}}\end{array}$ & $\begin{array}{r}-0.07^{\mathrm{ab}} \\
-0.28^{\mathrm{c}} \\
-0.70^{\mathrm{d}} \\
0.02^{\mathrm{a}}\end{array}$ \\
\hline \multicolumn{6}{|c|}{ Probability of greater $F$ value in ANOVA } \\
\hline $\begin{array}{l}\text { Wheat } \\
\text { Enzyme } \\
\text { Wheat } \times\end{array}$ & me & $\begin{array}{l}\star \star * \\
\text { NS } \\
\text { NS }\end{array}$ & $\begin{array}{c}\text { NS } \\
\star \star \\
\text { NS }\end{array}$ & $\begin{array}{c}* \star \star \\
* \\
\text { NS }\end{array}$ & $\begin{array}{c}\text { NS } \\
\star \star \star \\
\star \star\end{array}$ \\
\hline
\end{tabular}

$\mathrm{a}, \mathrm{b}, \mathrm{c}, \mathrm{d}, \mathrm{e}, \mathrm{f}, \mathrm{g}$ Values within a column with unlike superscript letters were significantly different $(P<0.05)$. ${ }^{\star} P<0.05,{ }^{* \star} P<0.01,{ }^{\star \star \star *} P<0.001$.

†For details of diets and procedures, see Table 1 and p. 54.

Table 8. lleal and caecal volatile fatty acid (VFA) production (mmol/bird) in broiler chickens fed on diets containing normalmetabolisable energy (ME) wheat and low-ME wheat with or without enzyme supplementation $\dagger$

(Mean values and standard deviations)

\begin{tabular}{|c|c|c|c|c|c|}
\hline \multirow[b]{2}{*}{ Wheat } & \multirow[b]{2}{*}{ Enzyme } & \multicolumn{2}{|c|}{$\begin{array}{l}\text { Ileal VFA pro- } \\
\text { duction }\end{array}$} & \multicolumn{2}{|c|}{$\begin{array}{c}\text { Caecal VFA pro- } \\
\text { duction }\end{array}$} \\
\hline & & Mean & SD & Mean & SD \\
\hline $\begin{array}{l}\text { Normal-ME } \\
\text { Normal-ME } \\
\text { Normal-ME } \\
\text { Normal-ME }\end{array}$ & $\begin{array}{l}\text { Control } \\
\text { Xylanase A } \\
\text { Xylanase B } \\
\text { Xylanase C }\end{array}$ & $\begin{array}{l}12 \cdot 6^{\mathrm{bc}} \\
11 \cdot 1^{\mathrm{bc}} \\
11 \cdot 5^{\mathrm{bc}} \\
12 \cdot 4^{\mathrm{bc}}\end{array}$ & $\begin{array}{l}4 \cdot 5 \\
3 \cdot 6 \\
3 \cdot 7 \\
4 \cdot 8\end{array}$ & $\begin{array}{l}788 \cdot 6^{a} \\
599 \cdot 5^{a} \\
748 \cdot 6^{a} \\
513 \cdot 4^{a}\end{array}$ & $\begin{array}{l}279 \cdot 8 \\
131 \cdot 6 \\
236 \cdot 1 \\
187 \cdot 4\end{array}$ \\
\hline $\begin{array}{l}\text { Low-ME } \\
\text { Low-ME } \\
\text { Low-ME } \\
\text { Low-ME }\end{array}$ & $\begin{array}{l}\text { Control } \\
\text { Xylanase A } \\
\text { Xylanase B } \\
\text { Xylanase C }\end{array}$ & $\begin{array}{l}26 \cdot 3^{\mathrm{a}} \\
12 \cdot 3^{\mathrm{bc}} \\
19 \cdot 5^{\mathrm{ab}} \\
10 \cdot 1^{\mathrm{c}}\end{array}$ & $\begin{array}{l}8 \cdot 0 \\
7 \cdot 9 \\
8 \cdot 8 \\
4 \cdot 5\end{array}$ & $\begin{array}{l}670 \cdot 1^{a} \\
697 \cdot 0^{a} \\
799 \cdot 7^{a} \\
561 \cdot 0^{a}\end{array}$ & $\begin{array}{l}167 \cdot 7 \\
276 \cdot 4 \\
313 \cdot 8 \\
270 \cdot 1\end{array}$ \\
\hline $\begin{array}{l}\text { Probability o } \\
\text { Wheat } \\
\text { Enzyme } \\
\text { Wheat } \times e\end{array}$ & reater $F$ value & $\begin{array}{r}\text { ANOVA } \\
\text { * } \\
\text { * }\end{array}$ & & & \\
\hline
\end{tabular}

a,b,c Mean values within a column with unlike superscript letters were significantly different $(P<0.05)$.

${ }^{*} P<0.05$.

†For details of diets and procedures, see Table 1 and p. 54

changes in digesta viscosity in the relevant sections. This is because xylanases differing in their substrate affinity should have contrasting effects on digesta viscosity and their ability to release soluble NSP in situ.

There have been numerous studies exploring the mechanisms by which supplemental xylanases improve the nutritive value of wheat-based diets for poultry. Soluble arabinoxylans in wheat are generally believed to be responsible for the majority of the anti-nutritive activity of NSP in poultry by virtue of their capacity to increase intestinal viscosity and modulate gut microflora (Choct et al. 1996). It is well recognised that increased viscosity decreases the digestion and absorption rate in the lumen by changing gastrointestinal functions (Edwards et al. 1988; Ikegami et al. 1990). In wheat-based diets, in particular, reduced performance is often related to an increase in intestinal viscosity (Bedford \& Classen, 1992). Furthermore, increased intestinal viscosity alters lipid and protein digestibility (Wang et al. 1992). The addition of commercial xylanases capable of degrading soluble NSP reduces viscosity and improves the nutritive value of wheat fed to chickens (Choct et al. 1994; Veldman \& Vahl, 1994; Dusel et al. 1998).

In the present study, xylanase A increased the soluble NSP levels in the jejunum of birds regardless of wheat type, and those in the ileum of birds fed the low-ME wheat. However, the increases in soluble NSP did not lead to elevated digesta viscosity, suggesting that whilst the enzyme attacked the insoluble cell walls of wheat to release soluble NSP into the digesta, it also effectively depolymerised the released NSP. On the other hand, xylanase B, a glycanase capable of attacking insoluble NSP, increased the soluble NSP levels in both the jejunum and ileum regardless of wheat type; the increases in soluble NSP levels, whilst comparable with that in birds fed diets containing xylanase A, were manifested in elevated digesta viscosity. This clearly suggests that xylanase B had no effect on the soluble NSP. As expected, xylanase C, an enzyme known to have affinity for only soluble NSP, effectively reduced digesta viscosity, presumably by cleaving the large molecules into smaller fragments. Since only high-molecular-weight soluble pentosans (molecular weight $>500000)$ are responsible for increased digesta viscosity (Bedford \& Classen, 1992), it was concluded that the released fragments had lower molecular weights. The finding that the concentration of free sugars in the ileum was elevated without a further increase in the concentration of soluble NSP indicates a continued depolymerisation of arabinoxylans throughout the intestine.

Third, the efficacies of the three xylanases in digesting the soluble and insoluble NSP were different. Xylanase A effectively degraded the insoluble NSP from the jejunum 
to ileum while maintaining a similar 'digestibility' value for the soluble NSP fraction. This means that this enzyme was able to degrade the NSP to molecular sizes lower than approximately ten sugar units (otherwise the sugars would have ended up in the soluble NSP fraction). On the other hand, xylanase B solubilised the insoluble NSP fraction in both wheats, making the digestibility of the soluble fraction more negative. This indicates clearly that this enzyme changed only the insoluble NSP:soluble NSP fractions ratio by solubilising the insoluble NSP without degrading them to monomeric or oligomeric sugars. Interestingly, xylanase $\mathrm{C}$ reduced digesta viscosity, but appeared to release soluble NSP in the jejunum of birds fed both the normal- and low-ME wheats as indicated by the negative digestibility values. This finding suggests that enzyme $\mathrm{C}$ was only able to reduce the molecular size of the soluble NSP in the jejunum, but as the digesta moved down the digestive tract it continuously worked on the substrates, resulting in the digestibility coefficients of soluble NSP being higher in the ileum. Furthermore, even though xylanase $\mathrm{C}$ was assumed to have affinity for only the soluble NSP fraction, in the present study the digestibility of the insoluble fraction of the low-ME wheat, but not for the normal wheat, by this enzyme was comparable with the other two enzymes. This highlights the differences between the two wheats in their cell-wall structures, and hence their susceptibility to digestibility by the natural gut microflora or an enzyme that usually degrades soluble substrates. For example, the digestibility values for the insoluble NSP were 7 and $14 \%$ in the jejunum and ileum, respectively, of birds fed the normal wheat, whereas the corresponding values were 26 and $25 \%$ for birds fed the low-ME wheat. These data seem to suggest that a normal wheat and a low-ME wheat differ not only in their total contents of viscous polysaccharides, but also in their cell-wall matrices where they are more susceptible to solubilisation in the gut for the low-ME wheat, elevating the viscosity of the digesta.

As mentioned earlier, viscosity reduction by xylanases A and $\mathrm{C}$ and improvement in bird performance appeared to confirm the findings that viscosity is the major contributor to the anti-nutritive effect of wheat NSP in poultry (Choct \& Annison, 1992b; Angkanaporn et al. 1994). However, the results related to the use of xylanase $\mathrm{B}$, a viscosityincreasing enzyme, that also enhanced the performance of birds and tended to increase AME, contradict the conventional theory of viscosity. One explanation is that the improvement in performance and energy utilisation is most probably due to the breakdown of arabinoxylansrich endosperm cell walls (Pettersson \& Åman, 1989; Bedford, 2002) and the subsequent release of intracellular encapsulated nutrients. These data confirm the conclusion that the ability of NSP to increase digesta viscosity depends on their solubility, molecular size and tertiary structures (Fincher \& Stone, 1982), and that quantitative measurements, such as the NSP level or digesta viscosity, should not be used as the sole indicator of the anti-nutritive activity of NSP in poultry diets.

The present results indicate that commercial glycanase products have beneficial effects in reducing the detrimental effects of wheat NSP both in low-ME and normal-ME wheat. The effect of the enzyme products used in the present study on the degradation of NSP clearly highlights the differences between xylanases. To fully understand the modes of action of the different xylanase products in poultry diets based on wheat, more detailed analyses of structural changes of the NSP are necessary.

\section{Acknowledgements}

The authors would like to thank Inge Knap and Anette Müllertz of Novo Nordisk, and Yvette Lieschke-Mercer, Mark Porter, Kylie Day, Maria Hyland, Shuyu Song, Gary Taylor and Grahame Chaffey from the University of New England for their technical support.

\section{References}

Angkanaporn K, Choct M, Bryden WL, Annison EF \& Annison G (1994) Effects of wheat pentosans on endogenous amino acid losses in chickens. J Sci Food Agric 66, 399-404.

Annison G (1991) Relationship between the levels of soluble nonstarch polysaccharides and the apparent metabolizable energy of wheats assayed in broiler chickens. J Agric Food Chem 39, $1252-1256$.

Annison G (1992) Commercial enzyme supplementation of wheat-based diets raises ileal glycanase activities and improves apparent metabolisable energy, starch and pentosan digestibilities in broiler chickens. Anim Feed Sci Technol 38, 105-121.

Annison G \& Choct M (1991) Anti-nutritive activities of cereal non-starch polysaccharides in broiler diets and strategies minimizing their effects. World's Poultry Sci J 47, 232-242.

Annison G, Choct M \& Hughes RJ (1994) AME determination and its application to lupins. Aust Poultry Sci Symp 6, 92-96.

Bedford MR (2002) The role of carbohydrases in feedstuff digestion. In Poultry Feedstuffs: Supply, Composition and Nutritive Value, pp. 319-336 [JM McNab and KN Boorman, editors]. London: CABI Publishing.

Bedford MR \& Classen HL (1992) Reduction of intestinal viscosity through manipulation of dietary rye and pentosanase concentration is effected through changes in the carbohydrate composition of the intestinal aqueous phase and results in improved growth rate and food conversion efficiency of broiler chicks. J Nutr 122, 560-569.

Choct M \& Annison G (1990) Anti-nutritive activity of wheat pentosans in broiler diets. Br Poultry Sci 31, 811-821.

Choct M \& Annison G (1992a) Anti-nutritive effect of wheat pentosans in broiler chickens: roles of viscosity and gut microflora. Br Poultry Sci 33, 821-834.

Choct M \& Annison G (1992b) The inhibition of nutrient digestion by wheat pentosans. Br J Nutr 67, 123-132.

Choct M, Hughes RJ, Trimble RP \& Annison G (1994) The use of enzymes in low-AME wheat broiler diets: effects on bird performance and gut viscosity. Aust Poultry Sci Symp 6, 83-87.

Choct M, Hughes RJ, Wang J, Bedford MR, Morgan AJ \& Annison G (1996) Increased small intestinal fermentation is partly responsible for the anti-nutritive activity of non-starch polysaccharides in chickens. Br Poultry Sci 37, 609-621.

Choct M \& Kocher A (2000) Xylanases of Different Origins: Effect on Nutritive Value of Wheat in Poultry. A Poultry Research Report. Armidale, NSW, Australia: University of New England.

Dusel G, Kluge H \& Jeroch H (1998) Xylanase supplementation of wheat-based rations for broilers: influence of wheat characteristics. J Appl Poultry Sci 7, 119-131.

Edwards CA, Johnson IT \& Read NW (1988) Do viscous 
polysaccharides slow absorption by inhibiting diffusion or convection? Eur J Clin Nutr 42, 306-312.

Fawcett R \& Webster M (1996) Valuing variance reduction. Aust Poultry Sci Symp 8, 53-64.

Fincher GB \& Stone BA (1982) Cell walls and their components in cereal grain technology. In Advances in Cereal Science and Technology, pp. 207-295 [Y Pomeranz, editor]. St Paul, MN: American Association of Cereal Chemists.

Ikegami S, Tsuchihashi F, Harada H, Tsuchihashi N, Nishide E \& Innami S (1990) Effect of viscous indigestible polysaccharides on pancreatic-biliary secretion and digestive organs in rats. $J$ Nutr 120, 353-360.

Manugistics, Inc. (2000) Statgraphics Plus for Windows. Rockville, MD: Manugistics, Inc.

Mollah Y, Bryden WL, Wallis IR, Balnave D \& Annison EF (1983) Studies on low metabolisable energy wheats for poultry using conventional and rapid assay procedures and the effect of processing. Br Poultry Sci 24, 81-89.

National Health \& Medical Research Council (1990) Australian Code of Practice for the Care and Use of Animals for Scientific Purposes. Canberra, Australia: Australian Government Publishing Services.

Petterson D \& Åman P (1989) Enzyme supplementation of a poultry diet containing rye and wheat. Br J Nutr 62, 139-149.
Philip JS, Gilbert HJ \& Smithard RR (1995) Growth, viscosity and beta-glucanase activity of intestinal fluid in broiler chickens fed on barley-based diets with or without exogenous beta-glucanase. Br Poultry Sci 36, 599-603.

Rogel AM, Annison EF, Bryden WL \& Balnave D (1987) The digestion of wheat starch in broiler chickens. Aust J Agric Res 38, 639-649.

SAS Institute, Inc. (1988) SAS Procedures Guide, Release 6.03 Cary, NC: SAS Institute, Inc.

Standing Committee on Agriculture and Resource Management (1995) Australian Model Code of Practice for the Welfare of Animals. Domestic Poultry. Melbourne, Australia: CSIRO.

Theander O \& Westerlund E (1993) Determination of individual components of dietary fiber. In Dietary Fiber in Human Nutrition, 2nd ed., pp. 77-98 [AG Spiller, editor]. Boca Raton, FL: CRC Press, Inc.

Veldman A \& Vahl HA (1994) Xylanase in broiler diets with differences in characteristics and content of wheat. Br Poultry Sci 35, 537-550.

Wang L, Newman RK, Newman CW \& Hofer PJ (1992) Barley beta-glucans alter intestinal viscosity and reduce plasma cholesterol concentrations in chicks. $J$ Nutr $\mathbf{1 2 2}$, 2292-2297. 